\title{
A new genus and species of fish blood fluke, Achorovermis testisinuosus gen. et sp. n. (Digenea: Aporocotylidae), infecting critically endangered smalltooth sawfish, Pristis pectinata (Rhinopristiformes: Pristidae) in the Gulf of Mexico
}

\author{
Micah B. Warren ${ }^{1}$, Micah D. Bakenhaster ${ }^{2}$, Rachel M. Scharer $^{3}$, Gregg R. Poulakis $^{3}$ and Stephen A. Bullard ${ }^{1}$ \\ ${ }^{1}$ Auburn University, School of Fisheries, Aquaculture \& Aquatic Sciences and Aquatic Parasitology Laboratory, Auburn, AL, USA; \\ ${ }^{2}$ Fish and Wildlife Research Institute, Florida Fish and Wildlife Conservation Commission, St. Petersburg, FL, USA; \\ ${ }^{3}$ Fish and Wildlife Research Institute, Florida Fish and Wildlife Conservation Commission, Charlotte Harbor Field Laboratory, Port \\ Charlotte, FL, USA
}

\begin{abstract}
Achorovermis testisinuosus gen. et sp. n. (Digenea: Aporocotylidae) infects the heart of the smalltooth sawfish, Pristis pectinata Latham (Rhinopristiformes: Pristidae), in the eastern Gulf of Mexico. Specimens of the new genus, along with the other blood flukes that infect batoids are similar by having an inverse U-shaped intestine and a curving testis as well as by lacking tegumental spines. The new genus differs from all of the other blood flukes infecting batoids by having an elongate body ( $>50 \times$ longer than wide), a testis having $>100$ curves, and an ovary wholly anterior to the uterus. It differs from Ogawaia glaucostegi Cutmore, Cribb et Yong, 2018 , the only other blood fluke infecting a rhinopristiform, by having a body that is $>50 \times(v s<30 \times)$ longer than wide, a testis that is $>75 \times(v s<40 \times)$ longer than wide and has $>100(v s<70)$ curves, an ovary wholly anterior to (vs lateral and dorsal to) the seminal vesicle, a uterus wholly posterior to ( $v s$ overlapping and lateral to both) the testis and ovary, and a sinuous ( $v s$ convoluted) uterus. The new species joins a small group of chondrichthyan blood flukes that lack tegumental spines: O. glaucostegi, Orchispirium heterovitellatum Madhavi et Rao, 1970, Myliobaticola richardheardi Bullard et Jensen, 2008, Electrovermis zappum Warren et Bullard, 2019. Blood flukes infecting batoids are further unique by having a curving testis. That is, the blood flukes infecting species within Selachii are morphologically distinct from those infecting species within the Batoidea (excluding Gymnurahemecus bulbosus Warren et Bullard, 2019). Based on the morphological similarity, we suspect that the new species shares a recent common ancestor with $O$. glaucostegi. The discovery of the new species brings the total number of chondrichthyan blood flukes to 11 species assigned to nine genera.
\end{abstract}

Keywords: taxonomy, systematics, Endangered Species Act, Chondrichthyes, Elasmobranchii, North America

Over half (90 of $166 \mathrm{spp}$. assigned to 40 genera) of the nominal fish blood flukes (Digenea: Aporocotylidae Odhner, 1912; see Bullard et al. 2009) have been discovered in the last 20 years. Of these, 18 have been described from North America (Table 1), including five infecting chondrichthyans (Bullard et al. 2006, Bullard and Jensen 2008, Orélis-Ribeiro et al. 2013, Warren and Bullard 2019, Warren et al. 2019). No blood fluke has been described from a sawfish (Rhinopristiformes: Pristidae) and only one other fish blood fluke, Ogawaia glaucostegi Cutmore, Cribb et Yong, 2018, has been described from a rhinopristiform.

The smalltooth sawfish, Pristis pectinata Latham (Rhinopristiformes: Pristidae), was the first elasmobranch to be listed as an endangered species under the United States Endangered Species Act (Simpfendorfer 2005), and the International Union for Conservation of Nature (IUCN) classified it as Critically Endangered in 2006 (Carlson et al. 2013). Gill netting and shrimp trawling contributed to the smalltooth sawfish decline (Seitz and Poulakis 2006). Collectively, 55 parasitic species have been reported from sawfishes (Pristidae: one species of Anoxypristis White et Moy-Thomas and four species of Pristis Linck): 23 cestodes (Southwell 1927, Watson and Thorson 1976, Campbell and Beveridge 1996, 2009, Beveridge and Campbell 2005, Schaeffner and Beveridge 2012, 2013, Cielocha et al. 2014, Bakenhaster et al. 2018, Caira et al. 2018); nine monogeneans (Watson and Thorson 1976, Cheung and Nigrelli 1983, Ogawa 1991, Chisholm and Whittington 1997, 2000, Kearn et al. 2010, Kritsky et al. 2017); seven copepods (Ogawa 1991, Morgan et al. 2010, Bakenhaster et al. 2018); four digeneans (Bakenhaster et al. 2018); four isopods (Moreira and Sadowsky 1978, Bakenhaster et al. 
2018); four leeches (Bakenhaster et al. 2018); three nematodes (Bruce et al. 1994, Bakenhaster et al. 2018); and one branchiuran (Bakenhaster et al. 2018). Of these 55, only one innominate aporocotylid (described herein) has been reported (Bakenhaster et al. 2018).

We herein describe a new species of blood fluke infecting the smalltooth sawfish from the eastern Gulf of Mexico. The new species is the first nominal blood fluke reported from a sawfish and the second blood fluke described from a rhinopristiform (Cutmore et al. 2018).

\section{MATERIALS AND METHODS}

Four smalltooth sawfish were processed as per Bakenhaster et al. (2018). Three uninfected smalltooth sawfish were collected from Biscayne Bay, Florida on 12 January 2012 and Caloosahatchee River, Florida on 8 November 2018 and 8 January 2019. The single sawfish that was infected was collected from the eastern Gulf of Mexico off Naples, Florida (30¹3'22.61"N; $88^{\circ} 3^{\prime} 18.57^{\prime \prime}$ ) on 2 July 2016. At necropsy, the heart, gill and spiral intestine were excised intact and separated (heart bisected, gill arches separated, spiral valve opened). All tissues were examined with the aid of a Leica M125 with simultaneous oblique-reflected and polarised substage light conditions to isolate fluke specimens for morphology. The heart was teased apart with forceps to reveal adult blood flukes, and sediment from the heart, gill, and spiral valve was examined with aid of a graduated cylinder after settling. Adult flukes $(n=9)$ were unmoving and presumed dead, so no attempt was made to relax them prior to their direct transfer to $5 \%$ neutral buffered formalin $(\mathrm{n}=9)$.

Adult flukes fixed in formalin were rinsed with distilled water, cleaned with fine brushes to remove any debris, stained overnight in Van Cleave's hematoxylin with several additional drops of Ehrlich's hematoxylin, dehydrated using an ethanol series, cleared in clove oil, permanently mounted in Canada balsam, illustrated using Leica DM 2500 and Leica DMR (Leica, Wetzler, Germany) microscopes each equipped with differential interference contrast (DIC), measured using an ocular micrometre, and illustrated using a drawing tube. Measurements are reported in micrometres $(\mu \mathrm{m})$ as the range followed by the mean and sample size in parentheses.

Scientific names, including taxonomic authorities and dates, for fishes follow Eschmeyer et al. (2016). Morphological terms and nomenclature for blood flukes follow Bullard et al. (2006, 2009), Bullard and Jensen (2008), Warren and Bullard (2019), and Warren et al. (2019). Specimens of a related aporocotylid (Ogawaia glaucostegi) were borrowed from the Queensland Museum (South Brisbane, Australia). Type and voucher materials of the new species were deposited in the National Museum of Natural History's Invertebrate Zoology Collection (USNM, Smithsonian Institution, Washington, D. C.). Bakenhaster et al. (2018) reported the specimens of the new species described herein but contained a lapse regarding infection intensity, which we correct herein in the taxonomic summary (see below).

\section{RESULTS}

Achorovermis Warren et Bullard gen. n.

Figs. 1-3

Generic diagnosis: Body extremely elongate, dorsoventrally flattened, having anterior and posterior ends tapering equally, aspinous. Rosethorn-shaped spines absent. Nervous system indistinct. Anterior sucker aspinous, lacking peduncle, diminutive. Mouth subterminal. Pharynx absent. Oesophagus extending sinuously posteriad along midline for $\leq 1 / 4$ of body length; posterior oesophageal swelling present. Intestine inverse U-shaped, asymmetrical; posterior caeca slightly shorter than oesophagus, connecting to oesophagus ventrally, lacking diverticulae, terminating in anterior half of body. Testis single, medial, curving, lacking lobed margins, wholly posterior to intestine. Vas deferens short, extending posteriad from testis. Cirrus-sac present, enveloping internal seminal vesicle and cirrus. Internal seminal vesicle distinct, longer than vas deferens. Cirrus short, $<14 \%$ of seminal vesicle length, curving sinistrally before everting. Auxiliary external seminal vesicle absent. Common genital pore dorsal, postgonadal, far anterior and sinistral to oötype. Ovary medial, postcaecal; postovarian space comprising $\geq 1 / 6$ of body length. Vitellarium follicular, diffuse, slightly asymmetrical, filling space between caecal bifurcation and testis. Laurer's canal absent. Oötype dextral, posterior to common genital pore, comprising an inconspicuous ovoid chamber. Uterus postgonadal, not extensively convoluted, extending posteriad from oötype before curving anteriad, crossing midline and extending posteriad; uterine eggs oblong. Uterine seminal receptacle absent. Excretory vesicle small, medial, with arms, visible in posterior most region of body.

Differential diagnosis (see Remarks): Body approx. 50$70 \times$ longer than wide; aspinous, lacking lateral tubercles. Anterior sucker aspinous, lacking peduncle, diminutive. Pharynx absent. Posterior oesophageal swelling present. Intestine inverse U-shaped, asymmetrical; posterior caeca terminating in anterior half of body, lacking diverticulae. Testis single, curving, lacking lobed margins, curving $>100$ times. Internal seminal vesicle distinct, longer than vas deferens, enveloped by cirrus sac. Cirrus short, $>8 \%$ of seminal vesicle length. Common genital pore postcaecal, postgonadal, far anterior and sinistral to oötype. Ovary medial, postcaecal, dorsal to posterior portion of testis, wholly anterior to uterus. Laurer's canal absent. Oötype posterior to common genital pore. Uterus postgonadal, dorsal and flanking seminal vesicle, not extensively convoluted; uterine eggs small, occupying $1 / 3$ of uterus.

\section{Taxonomic summary}

Type species: Achorovermis testisinuosus Warren et Bullard sp. n. (Digenea: Aporocotylidae).

Type host: Smalltooth sawfish, Pristis pectinata Latham (Rhinopristiformes: Pristidae).

E ty mology: 'Achoro' is for homeless considering the conservation status of its host and 'vermis' for worm.

\section{Remarks}

The new genus is most similar to the other blood flukes that infect batoids (Madhavi and Rao 1970, Bullard and Jensen 2008, Cutmore et al. 2018, Warren and Bullard 2019 [excluding Gymnurahemecus bulbosus Warren et Bullard, 2019]) by having an inverse U-shaped intestine and a curving testis as well as by lacking tegumental spines. It dif- 
A

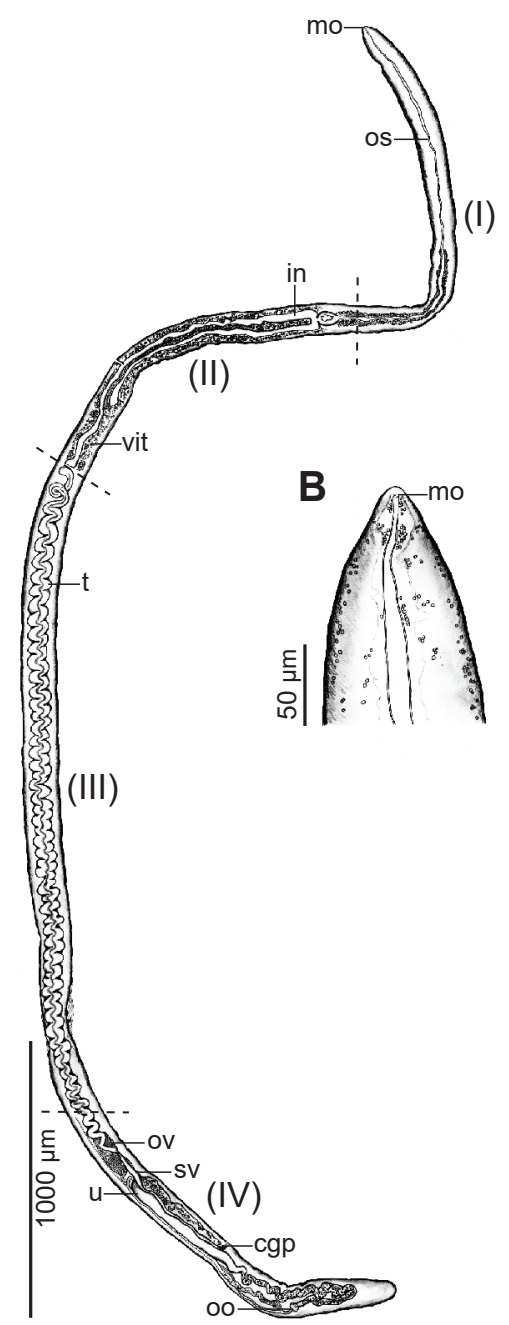

Fig. 1. Achorovermis testisinuosus Warren et Bullard gen. et sp. n. (Digenea: Aporocotylidae) from the heart of the smalltooth sawfish, Pristis pectinata Latham (Rhinopristiformes: Pristidae). A - body of holotype (USNM No. 1613421), ventral view. B - anterior sucker, holotype, ventral view. Abbreviations. mo - mouth; os - oesophagus; in - intestine; vit - vitellarium; $\mathrm{t}$ - testis; ov - ovary; $\mathrm{sv}$ - seminal vesicle; $\mathrm{u}$ - uterus; cgp - common genital pore; oo - oötype.

fers from all blood flukes infecting batoids by having the combination of an elongate body $(>50 \times$ longer than wide), a testis having $>100$ curves, and an ovary wholly anterior to the uterus.

Achorovermis testisinuosus Warren et Bullard sp. n.

Figs. 1-3

Description of adult (based on nine whole-mounted specimens; USNM coll. nos. 1613421-1613429):

Body 5,580-6,680 (6178; 4) long, 100-160 (116; 4) at greatest width, 49-67 $(57 ; 4) \times$ longer than wide (Fig. 1A). Nerve commissures and ventrolateral nerve-cords not evident in whole-mounts. Anterior sucker 13-15 $(14 ; 5)$ long, $16-19(17 ; 5)$ wide, aspinous, centered on mouth. Mouth $2-4(3 ; 6)$ in diameter, $7-10(8 ; 4)$ from terminal end of body (Fig. 1B). Oesophagus $1,030-1,420(1232 ; 5)$ in total length or $15-25 \%(21 \%$; 5$)$ of body length, $13-20$
$(16 ; 5)$ in maximum width (at level of precaecal dilation), with oesophageal wall gradually thickening and thinning throughout oesophagus (Figs. 1, 2A,B); oesophageal gland enveloping oesophagus anterior to precaecal dilation, 33$73(50 ; 6)$ long or $3-5 \%(4 \% ; 5)$ of oesophageal length, $25-53(31 ; 6)$ wide or $29-66 \%(44 \% ; 5)$ of body width (Figs. 1A, 2A,B). Caecal bifurcation 1,030-1,480 (1,248; 5) or $15-27 \%(21 \% ; 4)$ of body length from anterior body end; caeca extending posteriad in parallel, asymmetrical, dextral caecum $730-1,300(946 ; 4)$ long or $13-19 \%(16 \%$; 4) of body length, sinistral caecum 520-1,145 (767; 4) long or $9-17 \%(13 \%$; 4$)$ of body length, mean posterior caeca $13-41(24 ; 4)$ wide or $24-51 \%(35 \%$; 4$)$ of body width (Figs. 1A, 2B), containing granular material within lumen of some individuals.

Testis $1,950-3,820(2,703 ; 6)$ long or $37-63 \%(46 \% ; 4)$ of body length, 20-34 (26; 7) wide, occupying $50-60 \%$ $(56 \%$; 4) of body width, $78-191(108 ; 6) \times$ longer than wide, postcaecal, curving 109-129 $(119 ; 6)$ times (Figs. $1 \mathrm{~A}, 2 \mathrm{C})$ until narrowing and becoming confluent with vas deferens. (Figs. 2D, 3); post-testicular space 1,110-1,460 $(1,268 ; 6)$ long or $19-22 \%(21 \%$; 4$)$ of body length. Vas deferens $20-50(30 ; 6)$ long, $8-10(8 ; 6)$ wide, emanating from postero-ventral portion of testis, extending posterior for a short distance before connecting to cirrus sac (Figs. $2 \mathrm{D}, 3)$. Cirrus-sac having extremely thin wall, $1-3(2.4 ; 7)$ thick (Fig. 3), including seminal vesicle and cirrus; seminal vesicle extending sinuously posteriad, 353-555 (444; 7) long or $6-8 \%(7 \% ; 4)$ of body length, $13-20(15 ; 7)$ wide or $14-26 \%(19 \%$; 4$)$ of body width, running between ascending and descending portions of uterus, ultimately narrowing and curving sinistrally towards body margin (Figs. $1 \mathrm{~A}, 2 \mathrm{D}, 3)$; cirrus $40-78(55 ; 3)$ long or $9-14 \%(11 \% ; 3)$ of seminal vesicle length, $5-10(7.6 ; 5)$ wide or $33-71 \%$ $(53 \%$; 5) of seminal vesicle width (Fig. 3 ); everted cirrus short (Fig. 3), observed in two specimens, 10 and 18 (14; 2) long, 8 and $10(9 ; 2)$ wide, cirrus pore $10-18(13 ; 2)$ in diameter. Common genital pore $630-830(735 ; 7)$ or $9-14 \%(12 ; 4)$ of body length from posterior end of the body, 8-13 $(10 ; 7)$ from sinistral body margin, 60-88 (76; 7) from dextral body margin (Figs. 2D, 3).

Ovary medial, $123-140(132 ; 6)$ long or $2-3 \%(2 \% ; 4)$ of body length, $38-65(55 ; 7)$ wide or $45-52 \%(49 \%$; 4$)$ of body width, $2-3(2.3 ; 6) \times$ longer than wide, appears as aggregation of ova anterior to male and female reproductive ducts; postovarian space 1,010-1,250 $(1,105 ; 7)$ long or $17-19 \%(18 \% ; 4)$ of body length (Figs. 2D, 3). Oviduct originating from posterior margin of ovary, sharply curving twice before running dextrad and widening to form distal portion (Fig. 3); distal potion of oviduct a narrow tube extending approximately in parallel with and between body margin and ascending uterus, 653-796 (704: 6) long or 11$12 \%(11.3 ; 3)$ of body length, $10-18(14 ; 6)$ in maximum width, curving sinistrally toward medial body line body, then curving dextral before connecting with primary vitelline duct (Figs. 2D, 3). Primary vitelline duct 702-1050 $(806 ; 6)$ long, $5-10(8 ; 6)$ wide, indistinct anterior of ovary. Laurer's canal not observed. Oötype 25-30 $(27 ; 6)$ long, 23-30 (26; 6) wide (Figs. 2D, 3). 

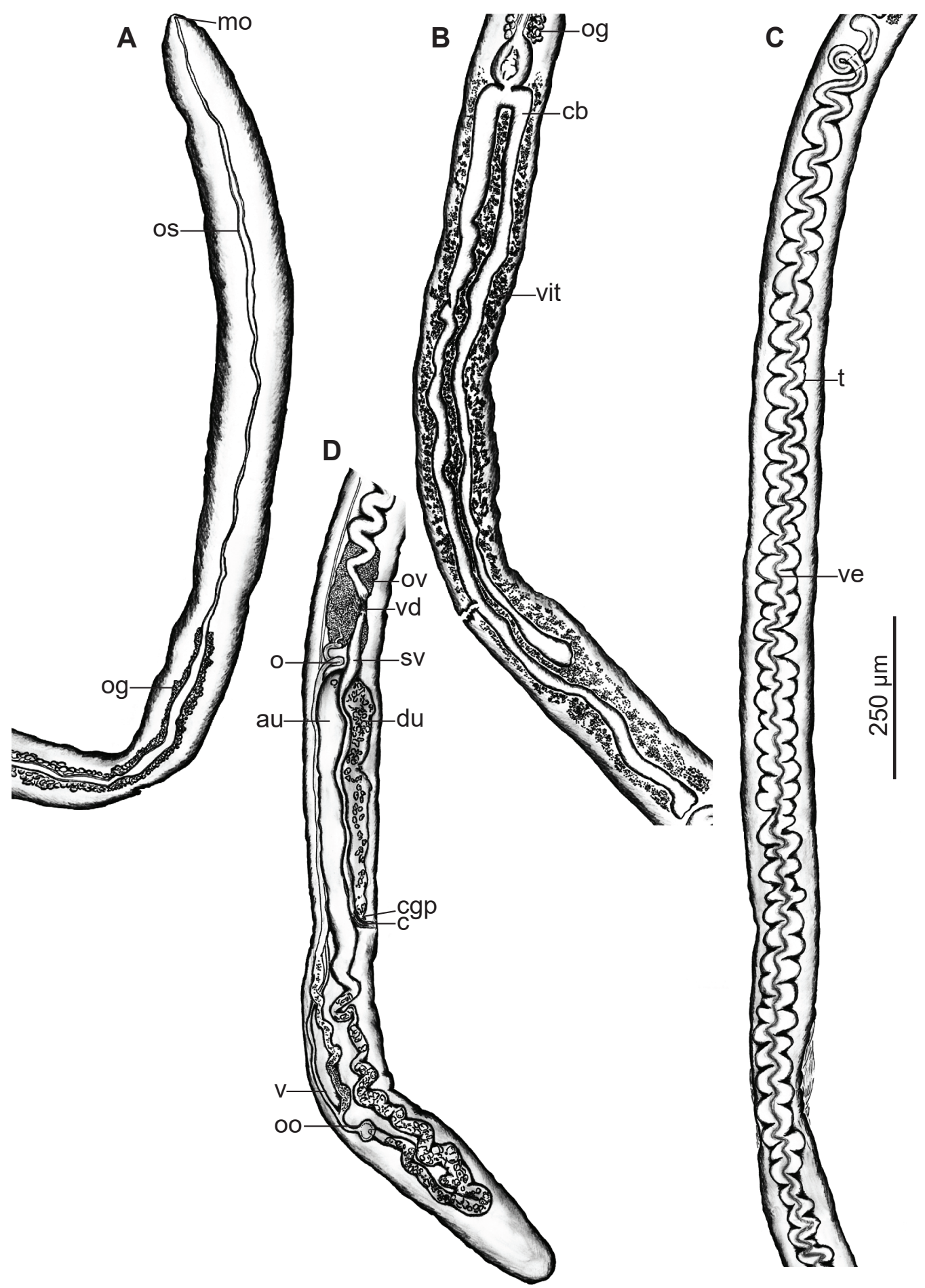

Fig. 2. Achorovermis testisinuosus Warren et Bullard gen. et sp. n. (Digenea: Aporocotylidae) from the heart of the smalltooth sawfish, Pristis pectinata Latham (Rhinopristiformes: Pristidae). A - anterior body segment (I); B - body segment (II); C - body segment (III); D - Posterior body segment (IV). Abbreviations: mo - mouth; os - oesophagus; og - oesophageal gland; cb - caecal bifurcation; vit - vitellarium; $\mathrm{t}$ - testis; ve - vasa efferentia; vd - vas deferens; ov - ovary; sv - seminal vesicle; o - oviduct; au - ascending uterus; $\mathrm{du}$ - descending uterus; cgp - common genital pore; $\mathrm{c}$ - cirrus; $\mathrm{v}$ - vitelline duct; oo - oötype.

Uterus extending directly posterior from oötype 618$856(709 ; 7)$ long, $18-28(24 ; 7)$ in maximum width, before looping back anteriorly $133-238(175 ; 7)$ from posterior end and connecting to ascending portion (Fig. 3); total ascending portion $403-698(548 ; 7)$ long or $13-17 \%(15 \% ; 3)$ of body length, 30-53 $(43 ; 7)$ wide (Fig. 3), sharply curving sinistrally to posterior margin of ovary, dorsal to sem- inal vesicle, before connecting with descending portion; descending portion extends posteriorly 297-416 $(360 ; 7)$ long or $5-6 \%(5.7 ; 3)$ of body length, $20-35(28 ; 7)$ wide. Uterine eggs $8-13(10 ; 7)$ in diameter or $27-50 \%(36 \% ; 7)$ of uterus width, containing many small dense bodies, with thin shell (Fig. 3). Excretory vesicle 10-43 (19; 5) long, 3-15 (7; 5) wide, with arms 93 (1). 


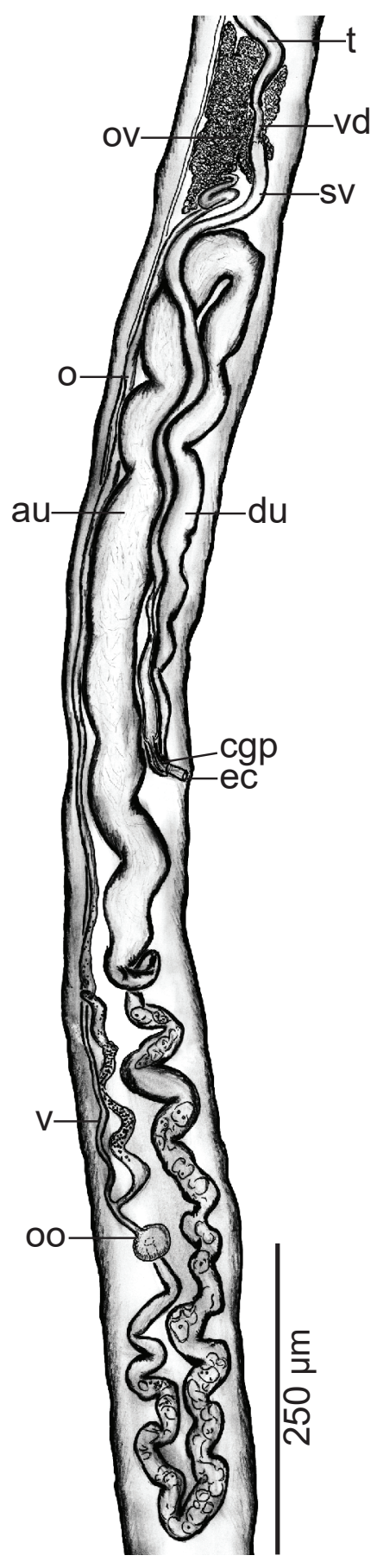

Fig. 3 Achorovermis testisinuosus Warren et Bullard gen. et sp. n. (Digenea: Aporocotylidae) from the heart of the smalltooth sawfish, Pristis pectinata Latham (Rhinopristiformes: Pristidae). Genitalia of paratype (USNM No. 1613422-1613429), ventral view. Abbreviations: t - testis; vd - vas deferens; ov - ovary; sv - seminal vesicle; o - oviduct; au -ascending uterus; du - descending uterus; cgp - common genital pore; ec - everted cirrus; $\mathrm{v}$ - vitelline duct; oo - oötype.

\section{Taxonomic summary}

Type and only reported host: Smalltooth sawfish, Pristis pectinata Latham (Rhinopristiformes: Pristidae).

Site in host: Heart lumen.

Type 1ocality: Off Naples, Florida $\left(30^{\circ} 13^{\prime} 22.61^{\prime \prime N}\right.$; $\left.88^{\circ} 3^{\prime} 18.57^{\prime \prime W}\right)$, eastern Gulf of Mexico, USA.
Prevalence and intensity of infection: One of four (prevalence $=25 \%$ ) smalltooth sawfish sampled on 12 January 2012, 2 July 2016, 8 November 2018, and 8 January 2019 was infected by 9 specimens of $A$. testisinuosus.

Specimens deposited: Holotype (USNM 1613421), paratypes (USNM 1613422-1613429).

E t y m ology: The specific epithet 'testisinuosus' refers to the many curves of the testis.

\section{DISCUSSION}

The new species is most similar to Ogawaia glaucostegi and the other blood flukes that infect batoids (Madhavi and Rao 1970, Bullard and Jensen 2008, Warren and Bullard 2019 [excluding Gymnurahemecus bulbosus, which has $\mathrm{C}$-shaped spines]) by the combination of having a diminutive anterior sucker that lacks spines, an asymmetrical, inverse U-shaped intestine, a curving testis, an internal seminal vesicle and cirrus sac, and a postcaecal common genital pore as well as by lacking lateral tegumental spines. It differs from $O$. glaucostegi by the combination of having a body that is $>50 \times(v s<30 \times)$ longer than wide, a testis that is $>75 \times(v s<40 \times)$ longer than wide and has $>100$ $(v s<70)$ curves, an ovary wholly anterior to (vs lateral and dorsal to) the seminal vesicle, a uterus wholly posterior to (vs overlapping and lateral to both) the testis and ovary, and a sinuous ( $v s$ convoluted) uterus.

The new species differs from Orchispirium heterovitellatum Madhavi et Rao, 1970 and Myliobaticola richardheardi Bullard et Jensen, 2008 by the combination of having a body that is $>50$ ( vs 3$) \times$ longer than wide, a testis with $>100$ (vs 21 and 10, respectively) curves, and a uterus that is sinuous ( $v s$ extensively convoluted). Further, $O$. heterovitellatum differs by having lateral tubercles along the body, an intestine bearing diverticula, and a testis that is inter-caecal and that has lobed margins. Achorovermis testisinuosus lacks lateral tubercles along the body margin, diverticula, and lobed margins along the testis as well as a testis that is wholly postcaecal. Myliobaticola richardheardi further differs by having a winding ( $v s$ sinuous) oesophagus and seminal vesicle.

The new species differs from Electrovermis zappum Warren et Bullard, 2019 by the combination of having a body that is $>50 \times(v s<40 \times)$ longer than wide, a testis that is $>30 \%(v s<20 \%)$ of the body length and has $>100$ $(v s<40)$ curves, a seminal vesicle that occupies $<17 \%$ (vs $>40 \%$ ) of the body, a cirrus that is $<15 \%$ (vs $65 \%$ ) of the seminal vesicle length, and an ovary that is $<20 \%$ ( $v s$ $>30 \%$ ) of the body length from the posterior body end.

The new species is the fifth chondrichthyan blood fluke that lacks spines, and all of these species infect batoids (Madhavi and Rao 1970, Bullard and Jensen 2008, Cutmore et al. 2018, Warren and Bullard 2019). Based on the morphological similarity we infer that the new species shares a recent common ancestor with $O$. glaucostegi. The remaining nominal chondrichthyan blood flukes have large $\mathrm{C}$-shaped spines. Four of these infect sharks: Hyperandrotrema cetorhini Maillard et Ktari, 1978, H. walterboegeri Orélis-Ribeiro et Bullard, 2013, Selachohemecus olsoni Short, 1954, S. benzi Bullard, Overstreet et Carlson, 2006; 
Table 1. Fish blood flukes (Digenea: Aporocotylidae) described from North America since 2000.

\begin{tabular}{|c|c|c|c|}
\hline Parasite & Host & Locality & Reference \\
\hline $\begin{array}{l}\text { Acipensericola glacialis Warren et } \\
\text { Bullard, } 2017\end{array}$ & $\begin{array}{l}\text { lake sturgeon, Acipenser fulvescens } \\
\text { Rafinesque }\end{array}$ & Lake Winnebago, Wisconsin, USA & Warren et al. 2017 \\
\hline $\begin{array}{l}\text { Acipensericola petersoni Bullard, } \\
\text { Snyder, Jensen et Overstreet, } 2008\end{array}$ & $\begin{array}{l}\text { American paddlefish, Polyodon } \\
\text { spathula (Walbaum) }\end{array}$ & $\begin{array}{l}\text { Mississippi River and Tennessee River } \\
\text { (Mississippi River Basin), USA }\end{array}$ & Bullard et al. 2008 \\
\hline $\begin{array}{l}\text { Cardallagium anthicum (as } \\
\text { Psettarium) Bullard et Overstreet, } \\
2006\end{array}$ & $\begin{array}{l}\text { cobia, Rachycentron canadum } \\
\text { (Linnaeus) }\end{array}$ & $\begin{array}{l}\text { Northern Gulf of Mexico } \sim 50 \mathrm{~km} \text { south/ } \\
\text { southeast of Ocean Springs, Mississippi, } \\
\text { USA }\end{array}$ & Bullard and Overstreet 2006 \\
\hline $\begin{array}{l}\text { Cardicola currani Bullard et } \\
\text { Overstreet, } 2004\end{array}$ & $\begin{array}{l}\text { red drum, Sciaenops occellatus } \\
\text { (Linnaeus) }\end{array}$ & $\begin{array}{l}\text { Northern Gulf of Mexico, Davis Bayou, } \\
\text { Mississippi Sound, Ocean Springs, } \\
\text { Mississippi, USA }\end{array}$ & Bullard and Overstreet 2004 \\
\hline Cardicola langeli Bullard, 2013 & $\begin{array}{l}\text { sheepshead, Archosargus } \\
\text { probatocephalus } \text { Walbaum }\end{array}$ & $\begin{array}{l}\text { Northern Gulf of Mexico off Horn Island, } \\
\text { Mississippi sound, Mississippi, USA }\end{array}$ & Bullard 2013 \\
\hline Cardicola nonamo Bullard, 2009 & $\begin{array}{l}\text { white seaperch, Phanerodon } \\
\text { furcatus Girard }\end{array}$ & $\begin{array}{l}\text { Eastern Pacific Ocean, Monterey Bay, } \\
\text { California, USA }\end{array}$ & Bullard 2010 \\
\hline $\begin{array}{l}\text { Cardicola palmeri Bullard et } \\
\text { Overstreet, } 2004\end{array}$ & $\begin{array}{l}\text { black drum, Pogonias cromis } \\
\text { (Linnaeus) }\end{array}$ & $\begin{array}{l}\text { Mississippi Sound off Point Cadet, Biloxi, } \\
\text { Mississippi, USA }\end{array}$ & Bullard and Overstreet 2004 \\
\hline $\begin{array}{l}\text { Cardicola parvus Bullard, Baker et } \\
\text { de Buron, } 2012\end{array}$ & $\begin{array}{l}\text { Atlantic croaker, Micropogonias } \\
\text { undulatus (Linnaeus) }\end{array}$ & $\begin{array}{l}\text { South Atlantic Bight off Cow Island, North } \\
\text { Carolina, USA }\end{array}$ & Bullard et al. 2012 \\
\hline $\begin{array}{l}\text { Elaphrobates euzeti Bullard et } \\
\text { Overstreet, } 2003\end{array}$ & $\begin{array}{l}\text { red snapper, Lutjanus campechanus } \\
\text { (Poey) }\end{array}$ & $\begin{array}{l}\text { Northern Gulf of Mexico } \sim 50 \mathrm{~km} \text { south of } \\
\text { Ocean Springs, Mississippi, USA }\end{array}$ & Bullard and Overstreet 2003 \\
\hline $\begin{array}{l}\text { Electrovermis zappum Warren et } \\
\text { Bullard, } 2019\end{array}$ & $\begin{array}{l}\text { lesser electric ray, Narcine bancroftii } \\
\text { (Griffith et Smith) }\end{array}$ & $\begin{array}{l}\text { Northern Gulf of Mexico off Fort Morgan, } \\
\text { Alabama, USA }\end{array}$ & Warren and Bullard 2019 \\
\hline $\begin{array}{l}\text { Elopicola franksi Orélis-Ribeiro et } \\
\text { Bullard, } 2017\end{array}$ & $\begin{array}{l}\text { tarpon, Megalops atlanticus } \\
\text { (Valenciennes) }\end{array}$ & $\begin{array}{l}\text { North Captiva Island and Bayboro Harbor, } \\
\text { off Florida, Gulf of Mexico, USA }\end{array}$ & Orélis-Ribeiro et al. 2017 \\
\hline $\begin{array}{l}\text { Elopicola nolancribbi Bullard, } \\
2014\end{array}$ & lady fish, Elops saurus Linnaeus & $\begin{array}{l}\text { Northern Gulf of Mexico off Ship Island, } \\
\text { Mississippi sound, Mississippi, USA }\end{array}$ & Bullard 2014 \\
\hline $\begin{array}{l}\text { Gymmurahemecus bulbosus Warren } \\
\text { et Bullard, } 2019\end{array}$ & $\begin{array}{l}\text { smooth butterfly ray, Gymnura } \\
\text { micrura (Bloch et Schneider) }\end{array}$ & $\begin{array}{l}\text { Northern Gulf of Mexico, Mobile, } \\
\text { Alabama, USA }\end{array}$ & Warren et al. 2019 \\
\hline $\begin{array}{l}\text { Hyperandrotrema walterboegeri } \\
\text { Orélis-Ribeiro et Bullard, } 2013\end{array}$ & $\begin{array}{l}\text { shortfin mako shark, Isurus } \\
\text { oxyrinchus Rafinesque }\end{array}$ & $\begin{array}{l}\text { Northern Gulf of Mexico, Viosca Knoll, } \\
\sim 123 \mathrm{~km} \text { south/southwest of Dauphin } \\
\text { Island, Alabama, USA }\end{array}$ & Orélis-Ribeiro et al. 2013 \\
\hline $\begin{array}{l}\text { Littorellicola billhawkinsi Bullard, } \\
2010\end{array}$ & $\begin{array}{l}\text { Florida pompano, Trachinotus } \\
\text { carolinus (Linnaeus) }\end{array}$ & $\begin{array}{l}\text { Northern Gulf of Mexico off Ship Island, } \\
\text { Mississippi sound, Mississippi, USA }\end{array}$ & Bullard 2010 \\
\hline $\begin{array}{l}\text { Myliobaticola richardheardi Bullard } \\
\text { et Jensen, } 2008\end{array}$ & $\begin{array}{l}\text { Atlantic stingray, Hypanus sabinus } \\
\text { (Lesueur, 1824) }\end{array}$ & $\begin{array}{l}\text { Northern Gulf of Mexico off Biloxi, Deer } \\
\text { Island, Mississippi Sound, Mississippi, } \\
\text { USA }\end{array}$ & Bullard and Jensen 2008 \\
\hline Pearsonellum lemusi Bullard, 2012 & $\begin{array}{l}\text { gag grouper, Mycteroperca microlepis } \\
\text { (Goode et Bean) }\end{array}$ & $\begin{array}{l}\text { North central Gulf of Mexico, Gulf of } \\
\text { Mexico, Groper reef, } \sim 80 \mathrm{~km} \text { south of } \\
\text { Dauphin Island, Alabama, USA }\end{array}$ & Bullard 2012 \\
\hline $\begin{array}{l}\text { Selachohemecus benzi Bullard, } \\
\text { Overstreet et Carlson, } 2006\end{array}$ & $\begin{array}{l}\text { blacktip shark, Carcharhinus } \\
\text { limbatus (Valenciennes) }\end{array}$ & $\begin{array}{l}\text { Apalachicola Bay, Florida, USA Northern } \\
\text { Gulf of Mexico, off Mississippi, USA }\end{array}$ & Bullard et al. 2006 \\
\hline $\begin{array}{l}\text { Achorovermis testisinuosus Warren } \\
\text { et Bullard gen. et sp. n. }\end{array}$ & $\begin{array}{l}\text { smalltooth sawfish, Pristis } \\
\text { pectinata Latham }\end{array}$ & $\begin{array}{l}\text { Eastern Gulf of Mexico off Naples, } \\
\text { Florida, USA }\end{array}$ & present study \\
\hline
\end{tabular}

one infecting a holocephalan: Chimaerahemecus trondheimensis Van der Land, 1967, and one infects a batoid: Gymnurahemecus bulbosus (see Short 1954, Van der Land 1967, Maillard and Ktari 1978, Bullard et al. 2006, Orélis-Ribeiro et al. 2013, Warren et al. 2019).

Shirai $(1992,1996)$ formalised two lineages of elasmobranchs: Galea (including Orectolobiformes, Lamniformes, and Carcharhiniformes) and Squalea (including Chlamydoselachiformes, Hexanchiformes, Echinorhiniformes, Dalatiiformes, Centrophoriformes, Squaliformes, and all batoids). Last et al. (2016) recovered a phylogenetic tree to test batoid interrelationships wherein Rajidae was recovered sister to all other batoids. This contradicts Shirai's analysis that instead recovered Pristidae as such. More recently, Amaral et al. (2018) produced a mitogenomic phylogeny for the elasmobranchs and recovered Batoidea as sister to the Selachii (including Galeomorphii and Squalimorphii). This tree also recovers a clade including Rajoidei sister to Torpedinoidei that is sister to all other batoids.

Based on morphology, the blood flukes of selachians and batoids are likely monophyletic, evidently closely related, and likely share a recent common ancestor. For example, species of Hyperandrotrema and species of Selachohemecus infect lamniform and carcharhiniform sharks (Galeomorphii), respectively, and species of both genera have C-shaped spines. Ogawaia glaucostegi, $M$. richardheardi, O. heterovitellatum, and E. zappum all infect batoids (Batoidea) and lack tegumental spines. However, $C$. trondheimensis and $G$. bulbosus are distinct by having $\mathrm{C}$-shaped spines and infecting a holocephalan and a batoid, respectively.

Further, none of the nominal chondrichthyan blood flukes that have $\mathrm{C}$-shaped spines have a curving testis like those infecting batoids (excluding G. bulbosus). Further still, C. trondheimensis, H. cetorhini, H. walterboegeri, and G. bulbosus have an oötype that is located posterior to all other genitalia, unlike Selachohemecus spp. that have an oötype that is dorsal to the ascending uterus (Van der Land 1967, Maillard and Ktari 1978, Bullard et al. 2006, Orélis-Ribeiro et al. 2013, Warren et al. 2019). Additionally, S. olsoni and S. benzi differ from the nine other nominal chondrichthyan blood flukes by having an X-shaped ( $v s$ inverse U-shaped) intestine. This feature has been observed only in fish blood flukes infecting later branching rayfinned fishes (Actinopterygii) (see Bullard and Overstreet 2006, Bullard 2010). These morphological differences are 
predictive of shared ancestry and so far agree with existing molecular phylogenetic analyses that recover monophyletic chondrichthyan blood flukes (Warren and Bullard 2019, Warren et al. 2019).

Acknowledgments. We thank Jason Tidwell (Florida Fish and Wildlife Conservation Commission [FWC], Law Enforcement) and James Case (FWC volunteer) for collecting the infected smalltooth sawfish; Yasunari Kiryu, Maki Tabuchi, Courtney Saari (all FWC) and Josh Saari (FWC volunteer) for conducting necropsies; Theresa Cody (FWC) for allocating critical programmatic resources; and especially Mal Bryant and Robert Adlard (Queensland Museum) for loaning the type specimens of Ogawaia glaucostegi. This study was supported by Auburn University Vice President for Research and Economic Development, Southeastern Cooperative Fish Parasite and Disease Project (Alabama Department of Conservation and Natural Resources), Alabama Agriculture Experiment Station, and U.S. Department of Agriculture. Funding for this research was also provided in part by the U.S. Department of Commerce (DOC), National Ocean- ic and Atmospheric Administration's (NOAA) National Marine Fisheries Service (NMFS) through Section 6 (Cooperation with the States) of the U.S. Endangered Species Act under the following grant award to FWRI from the DOC, NOAA-NA16NMF4720062. Funding for collection of parasites was from State of Florida saltwater recreational fishing license revenues, and the U.S. Department of the Interior (DOI) U.S. Fish and Wildlife Service (USFWS) Wildlife and Sport Fish Restoration program (WSFR) [FL-F- 2-16, F16AF00544, and F18AF00524]. Statements, findings, conclusions, and recommendations are those of the authors and do not necessarily reflect the views or policies of the DOC, NOAA, DOI, or the USFWS. This research was conducted under Endangered Species Permit 15802 (FWC) issued by the NMFS. Any opinions, views, statements, findings, conclusions, and recommendations expressed in this material are those of the authors; they do not necessarily reflect, and should not be interpreted as representing, the opinions, views, or policies of the USFWS, WSFR, NOAA, NMFS, DOI, or DOC. Nothing contained herein constitutes an endorsement in any respect by any part of the U.S. Government or the State of Florida.

\section{REFERENCES}

Amaral C.R.L., Pereira F., Silva D.A., Amorim A., de CarVALHO E.F. 2018: The mitogenomic phylogeny of the Elasmobranchii (Chondrichthyes). Mitochondrial DNA A DNA Mapp. Seq. Anal. 29: 867-878.

Bakenhaster M.D., Bullard S.A., Curran S.S., Kritsky D.C., Leone E.H., Partridge L.K., Ruiz C.F., Scharer R.M., Poulakis G.R. 2018: Parasite component community of smalltooth sawfish off Florida: diversity, conservation concerns, and research applications. Endang. Species Res. 35: 47-58.

Beveridge I., CAmpbell R.A. 2005: Three new genera of trypanorhynch cestodes from Australian elasmobranch fishes. Syst. Parasitol. 60: 211-224.

Bruce N.L., Cannon L.R.G., Adlard R. 1994: Synoptic checklist of ascaridoid parasites (Nematoda) from fish hosts. Invertebr. Taxon. 8: 583-674.

Bullard S.A. 2010: A new species of Cardicola Short, 1953 (Digenea: Aporocotylidae) from the heart and branchial vessels of two surfperches (Embiotocidae) in the Eastern Pacific Ocean off California. J. Parasitol. 96: 382-388.

Bullard S.A. 2012: Pearsonellum lemusi n. sp. (Digenea: Aporocotylidae) from blood vascular system of gag grouper, Mycteroperca microlepis (Perciformes: Serranidae), off Alabama, with an emendation of Pearsonellum Overstreet and Køie, 1989. J. Parasitol. 98: 323-327.

Bullard S.A. 2013: Cardicola langeli sp. n. (Digenea: Aporocotylidae) from heart of sheepshead, Archosargus probatocephalus (Actinopterygii: Sparidae) in the Gulf of Mexico, with an updated list of hosts, infection sites and localities for Cardicola spp. Folia Parasitol. 60: 17-27.

Bullard S.A. 2014: Blood flukes (Digenea: Aporocotylidae) of Elopomorpha: emended diagnosis of Paracardicoloides, supplemental observations of Paracardicoloides yamagutii, and a new genus and species from ladyfish, Elops saurus in the northern Gulf of Mexico. J. Parasitol. 100: 305-316.

Bullard S.A., Baker T., De Buron I. 2012: New species of Cardicola (Digenea: Aporocotylidae) from heart of Atlantic croaker, Micropogonias undulatus (Perciformes: Sciaenidae), of the south Atlantic Bight. J. Parasitol. 98: 328-332.

Bullard S.A., Jensen K. 2008: Blood flukes (Digenea: Aporocotylidae) of stingrays (Myliobatiformes: Dasyatidae): Orchispirium heterovitellatum from Himantura imbricata in the Bay of Bengal and a new genus and species of Aporocotylidae from
Dasyatis sabina in the northern Gulf of Mexico. J. Parasitol. 94: 1311-1321.

Bullard S.A., Jensen K., Overstreet R.M. 2009. Historical account of the two family-group names in use for the single accepted family comprising the "fish blood flukes". Acta Parasitol. 54: 78-84.

Bullard S.A., Overstreet R.M. 2003: Elaphrobates euzeti gen. and sp. n. (Digenea: Sanguinicolidae) from snappers (Lutjanidae) in the Gulf of Mexico. In C. Combes and J. Jourdane (Eds.), Taxonomy, Ecology and Evolution of Metazoan Parasites. Presses Universitaires de Perpignan, Perpignan, pp. 97-113

Bullard S.A., Overstreet R.M. 2004: Two new species of Cardicola Short, 1953 (Digenea: Sanguinicolidae) from the heart drums (Sciaenidae) in the Northern Gulf of Mexico. J. Parasitol. 90: 128-136.

Bullard S.A., Overstreet R.M. 2006: Psettarium anthicum sp. n. (Digenea: Sanguinicolidae) from the heart of cobia Rachycentron canadum (Perciformes: Rachycentridae) in the northern Gulf of Mexico. Folia Parasitol. 53: 117-124.

Bullard S.A., Overstreet R.M., Carlson, J.K. 2006: Selachohemecus benzi n. sp. (Digenea: Sanguinicolidae) from the blacktip shark Carcharhinus limbatus (Carcharhinidae) in the northern Gulf of Mexico. Syst. Parasitol. 63: 143-154.

Bullard S.A., Snyder S.D., Jensen K., Overstreet R.M. 2008: New genus and species of Aporocotylidae (Digenea) from a basal Actinopterygian, the American paddlefish, Polyodon spathula, (Acipenseriformes: Polyodontidae) from the Mississippi Delta. J. Parasitol. 94: 487-495.

Caira J.N., Jensen K., Fyler C.A. 2018: A new genus of tapeworm (Cestoda: Onchoproteocephalidea) from sawfish (Elasmobranchii: Pristidae). J. Parasitol. 104: 133-144.

Campbell R.A., Beveridge I. 1996: Revision of the family Pterobothriidae Pintner, 1931 (Cestoda: Trypanorhyncha). Invertebr. Taxon. 10: 617-662.

Campbell R.A., Beveridge I. 2009: Oncomegas aetobatidis sp. nov. (Cestoda: Trypanorhyncha), a re-description of $O$. australiensis Toth, Campbell \& Schmidt, 1992 and new records of trypanorhynch cestodes from Australian elasmobranch fishes. Trans. Royal Soc. S. Australia 133: 18-29.

Carlson J., Wiley T., Smith K. 2013: Pristis pectinata (errata version published in 2019). The IUCN Red List of Threatened Species 2013: e.T18175A141791261. http://dx.doi.org/10.2305/ IUCN.UK.2013-1.RLTS.T18175A141791261.en (accessed $1 \mathrm{Au}-$ gust 2019). 
Cheung P.J., Nigrelli R.F. 1983: Dermophthirioides pristidis n. gen., n. sp. (Microbothriidae) from the skin and Neoheterocotyle ruggierii $\mathrm{n}$. sp. (Monocotylidae) from the gills of the smalltooth sawfish, Pristis pectinata. Trans. Amer. Microsc. Soc. 102 366-370.

Chisholm L.A., Whittington I.D. 1997: A revision of Neoheterocotyle (Monogenea: Monocotylidae) with descriptions of the larvae of $N$. rhinobatis and $N$. rhynchobatis from Heron Island, Great Barrier Reef, Australia. Int. J. Parasitol. 27: 1041-1060.

Chisholm L.A., Whittington I.D. 2000: A new species of $\mathrm{Ne}$ oheterocotyle Hargis, 1955 (Monogenea: Monocotylidae) from the gills of Pristis clavata Garman (Pristidae) from Darwin, Australia. Syst. Parasitol. 46: 93-98.

Cielocha J.J., Jensen K., Caira J.N. 2014: Floriparicapitus, a new genus of lecanicephalidean tapeworm (Cestoda) from sawfishes (Pristidae) and guitarfishes (Rhinobatidae) in the Indo-West Pacific. J. Parasitol. 100: 485-499.

Cutmore S.C., Cribb T.H., Yong R.Q.-Y. 2018: Aporocotylids from batoid and elopomorph fishes from Moreton Bay, Queensland, Australia, including a new genus and species of blood fluke infecting the giant shovelnose ray, Glaucostegus typus (Rhinopristiformes: Glaucostegidae). Parasitol. Int. 67: 768-775.

Eschmeyer W.N., Fricke R., Van Der Laan R. 2016: Catalog of Fishes: Genera, Species, References. (http://researcharchive. calacademy.org/research/ichthyology/fishcatmain.asp) (accessed 15 March 2019).

Kearn G.C., Whittington I.D., Evans-Gowing R. 2010 A new genus and new species of microbothriid monogenean (Platyhelminthes) with a functionally enigmatic reproductive system, parasitic on the skin and mouth lining of the largetooth sawfish, Pristis microdon, in Australia. Acta Parasitol. 55: 115-122.

Kritsky D.C., Bullard S.A., Bakenhaster M.D., Scharer R.M., Poulakis G.R. 2017: Resurrection of Mycteronastes (Monogenoidea: Monocotylidae), with description of Mycteronastes caalusi $\mathrm{n}$. sp. from olfactory sacs of the smalltooth sawfish, Pristis pectinata (Pristiformes: Pristidae), in the Gulf of Mexico off Florida. J. Parasitol. 103: 477-485.

Last P.R., White T.W., de Carvalho M.R., Séret S.B., StehMANN M.F.W., NAYLOR G.J.P. 2016: Rays of the World, Cornell University Press, Ithaca, $790 \mathrm{p}$.

Madhavi R., Hanumantha Rao K. 1970: Orchispirium heterovitellatum gen. et sp. nov. (Trematoda: Sanguinicolidae) from the ray fish, Dasyatis imbricatus Day, from Bay of Bengal. J. Parasitol. 56: 41-43.

Maillard C., Ktari M.H. 1978: Hyperandrotrema cetorhini $\mathrm{n}$. g., n. sp. (Trematoda, Sanguinicolidae) parasite du système circulatoire de Cetorhinus maximus (Selacii). Ann. Parasitol. Hum. Comp. 53: 359-365.

Moreira P.S., SAdowsky V. 1978: An annotated bibliography of parasitic Isopoda (Crustacea) of Chondrichthyes. Braz. J. Oceanogr. 27: 95-152.

Morgan D.L., Tang D., Peverell S.C. 2010: Critically endangered Pristis microdon (Elasmobranchii), as a host for the Indian parasitic copepod, Caligus furcisetifer Redkar, Rangnekar et Murti, 1949 (Siphonostomatoida): New records from northern Australia. Acta Parasitol. 55: 419-423.

Ogawa K. 1991: Ectoparasites of sawfish, Pristis microdon, caught in freshwaters of Australia and Papua New Guinea. In: M. Shimizu and T. Taniuchi (Eds.), Studies on elasmobranchs collected from seven river systems in northern Australia and Papua
New Guinea. University Museum, University of Tokyo. Nature Culture 3: 91-102.

Orélis-Ribeiro R., Halanych K.M., Dang B.T., Bakenhaster M.D., Arias C.R., Bullard S.A. 2017: Two new species of Elopicola (Digenea: Aporocotylidae) from Hawaiian ladyfish, Elops hawaiensis (Eastern Sea) and Atlantic tarpon, Megalops atlanticus (Gulf of Mexico) with a comment on monophyly of elopomorph blood flukes. Parasitol. Int. 66: 305-318.

Orélis-Ribeiro R., Ruiz C.F., Curran S.S., Bullard S.A. 2013: Blood flukes (Digenea: Aporocotylidae) of epipelagic lamniforms: redescription of Hyperandrotrema cetorhini from basking shark (Cetorhinus maximus) and description of a new congener from shortfin mako shark (Isurus oxyrinchus) off Alabama. J. Parasitol. 99: 835-846.

Schaeffner B.C., Beveridge I. 2012: Prochristianella Dollfus, 1946 (Trypanorhyncha: Eutetrarhynchidae) from elasmobranchs off Borneo and Australia, including new records and the description of four new species. Zootaxa 3505: 1-25.

Schaeffner B.C., Beveridge I. 2013: Pristiorhynchus palmi $\mathrm{n}$. g., n. sp. (Cestoda: Trypanorhyncha) from sawfishes (Pristidae) off Australia, with redescriptions and new records of six species of the Otobothrioidea Dollfus, 1942. Syst. Parasitol. 84: 97-121.

Seitz J.C., Poulakis G.R. 2006: Anthropogenic effects on the smalltooth sawfish (Pristis pectinata) in the United States. Mar. Poll. Bull. 52: 1533-1540.

Shirai S. 1992: Squalean Phylogeny: A New Framework of 'Squaloid' Sharks and Related Taxa. Hokkaido University Press, Sapporo, $209 \mathrm{pp}$.

ShIRAI S. 1996: Phylogenetic interrelationships of neoselachians (Chondrichthyes: Euselachii). In: M.L.J. Stiassny, L.R. Parenti, and G.D. Johnson (Eds.), Interrelationships of Fishes. San Diego, California, Academic press, pp. 9-34.

Short R.B. 1954: A new blood fluke, Selachohemecus olsoni, n. g., n. sp. (Aporocotylidae) from the sharp-nosed shark, Scoliodon terranovae. Proc. Helminthol. Soc. Wash. 21: 78-82.

SimpFEndorfer C.A. 2005: Threatened fishes of the world: Pristis pectinata Latham, 1794 (Pristidae). Environ. Biol. Fish. 73: 20.

Southwell T. 1927: On a collection of cestodes from marine fishes of Ceylon and India. Ann. Trop. Med. Parasitol. 21: 351-373.

Van Der Land J. 1967: A new blood fluke (Trematoda) from Chimaera monstrosa L. Proc. Koninklijke Akad. Wetens. Amsterdam, S. C, Biol. Med. Sci. 70: 110-120.

Warren M.B., Bullard S.A. 2019: First elucidation of a blood fluke (Electrovermis zappum n. gen., n. sp.) life cycle including a chondrichthyan or bivalve. Int. J. Parasitol.: Parasit. Wild. 10: 170-183.

Warren M.B., Roberts J.R., Arias C.R., Koenigs R.P., BullARD S.A., 2017: Acipensericola glacialis n. sp. (digenea: Aporocotylidae) from heart of lake sturgeon Acipenser ful- vescens rafinesque (acipenseriformes: acipenseridae) in the great lakes bain, Lake Winnebago system, USA. Syst. Parasitol. 94: 875-889.

Warren M.B., Ruiz C.F., Whelan N.V., Bullard S.A. 2019: Gymnurahemecus bulbosus gen. et. sp. nov. (Digenea: Aporocotylidae) infecting smooth butterfly rays, Gymnura micrura (Myliobatiformes: Gymnuridae) in the northern Gulf of Mexico, with a taxonomic key and further evidence for monophyly of chondrichthyan blood flukes. Parasitol. Res. 118: 751-762.

WATSON D.E., THORSON T.B. 1976: Helminths from elasmobranchs in Central American fresh waters. In: T.B. Thorson (Ed.), Investigation of the Ichthyofauna of Nicaraguan lakes. University of Nebraska Press, Lincoln, pp. 629-640.

Cite this article as: Warren M.B., Bakenhaster M.D., Scharer R.M., Poulakis G.R., Bullard S.A. 2020: A new genus and species of fish blood fluke, Achorovermis testisinuosus gen. et sp. n. (Digenea: Aporocotylidae), infecting critically endangered smalltooth sawfish, Pristis pectinata (Rhinopristiformes: Pristidae) in the Gulf of Mexico. Folia Parasitol. 67: 009. 